\title{
MicroRNAs EXPRESSION PROFILE OF GEFITINIB RESISTANT NON-SMALL CELL LUNG CANCER HCC827 CELLS
}

\author{
Duong Hong Quan ${ }^{1,2 *}$, Yeon-Sun Seong ${ }^{2}$ \\ ${ }^{1}$ Duy Tan University, Da Nang, Vietnam \\ ${ }^{2}$ Dankook University, Cheonan, Republic of Korea, *quanvspt@gmail.com
}

\begin{abstract}
Epidermal growth factor receptor (EGFR) tyrosine kinase inhibitors (TKIs), such as gefitinib and erlotinib are promising therapies for patients with non-small-cell lung cancer (NSCLC). Patients with somatic activating mutations in the EGFR gene have dramatic response initially; however, these patients eventually develop resistance to these TKIs. Subsequent studies found that a secondary mutation in the EGFR gene (T790M mutation) and amplification of the cMET could be the two main resistance mechanism involved. Other mechanisms are still unknown. Recently, microRNAs (miRNAs) have been identified as important posttranscriptional regulators which are known in the regulation of gene expression for cell development, cell proliferation, radiotherapy and chemotherapy resistance and apoptotic cell death. The aim of this study was to investigate miRNA expression profiles involved in the development of gefitinib resistance in NSCLC. Here, miRNA microarray assay was employed to identify miRNA expression profiles in gefitinib-resistant HCC827 cells (HCC827/GR) and parental HCC827 cells (HCC827/P). The comparison of miRNA expression between HCC827/GR and HCC827/P cell lines identified the differential expression of sixty-five miRNAs with eight significantly upregulated miRNAs (miRNA-198, miR-202, miR-210, miRNA-214, miR-22, miR-27a, miR-296-3p and miR-208b) and fourteen greatly downregulated miRNAs (miR-135b, miR-141, miR-145, miR-153, miR-181c, miR-181d, miR-188-3p, miR-197, miR-200c, miR-206-3, miR-215, miR-216a, miR-296-5p and miR-30a). The investigation of miRNA expression profiles in HCC827/GR cells could provide a better understanding of mechanisms involved in gefitinib resistance or sensitivity which would be helpful to develop novel strategies to overcome gefitinib resistance of patients with NSCLC.
\end{abstract}

Keywords: miRNA expression profile, targeted therapy, resistance of gefitinib, non-small cell lung cancer, HCC827 cells.

\section{INTRODUCTION}

Lung cancer is the leading cause of cancerrelated deaths in the world and $85 \%$ of lung cancer is diagnosed as non-smal cell lung cancer (NSCLC), mainly consisting of adenocarcinoma, squamous cell and large-cell carcinoma [11]. Moreover, the prognosis of NSCLC patients remains unsatisfactory because many locally advanced or metastatic tumors are unresectable [10]. Even patients with early stages of the disease who undergo compete resections often experience recurrences, resulting in unfavorable outcomes. Recently, the epidermal growth factor receptor tyrosine kinase inhibitors (EGFR-TKIs) as gefitinib and erlotinib, have been used as the best approach to treat NSCLC patients $[16,19]$. However, most such patients ultimately develop resistance to these drugs. Among patients with NSCLC who develop resistance to the first generation EGFRTKIs, approximately half of resistant cases had EGFR T790M mutations and 20\% have tumors that manifest amplification of the protooncogene MET $[13,17,8]$ while other unknown mechanisms are still being investigated. Therefore, the identification of novel approach or agents capable of overcoming acquired resistance to EGFR-TKIs is very important clinical goal.

MicroRNAs (miRNAs) are small noncoding RNAs (20 to 22 nucleotides in length) and regulate gene expression at the posttranscriptional level by binding to complementary sequences on specific messenger RNA (mRNA) transcripts [9,1]. miRNAs has been known as critical regulator of many cellular processes as physiologic and pathologic process $[5,12]$. Moreover, the 
profiles of miRNA expression are very helpful for investigation of the prognosis and chemosensitivity as well as radiotherapy of human cancer. There are few studies showing miRNA expression patterns associated with chemotherapy and radiotherapy resistance in various kinds of cancer as the profile of miRNA expression in chemotherapy drugs (Cisplatin, Paclitaxel, and/or Cyclosporin A)-resistant ovarian cancer A2780 cell line [18]; the miRNA expression profile to predict gemcitabine resistance in Bladder carcinoma cell lines as RT4, J82 and TCCSUP cell lines [14]; the miRNA profile of paclitaxel-resistant serous ovarian carcinoma based on formalin-fixed paraffin embedded samples [15]; and miRNA expression and function in postoperative radiotherapy sensitive and resistant patients of non-small cell lung cancer [20]. Then, investigation of the miRNA expression profile in gefitinib resistance in NSCLC by using miRNA microarray will be useful to overcome the resistance of gefitinib in NSCLC.

In this study, we generated gefitinibresistant $\mathrm{HCC} 827$ cells (HCC827/GR) from well-characterized parental HCC827 cells (HCC827/P) and investigated the expression profile of miRNAs between HCC $827 / \mathrm{GR}$ and HCC 827/P cells. The miRNAs signature of gefitinib resistance could be used to develop new strategies for treatment of NSCLC patients with gefitinib in future.

\section{MATERIALS AND METHODS}

\section{Cell culture and reagents}

HCC827 cells were purchased from American Type Culture Collection (ATCC, Manassas, VA). HCC827 cells were cultured in Roswell Park Memorial Institute-1680 Medium (RPMI-1680) containing 10\% FBS, 2.5\% horse serum (HS), 100 units/ml penicillin, and 100 $\mu \mathrm{g} / \mathrm{ml}$ streptomycin. Cell culture reagents were purchased from BioWhittaker (Walkersville, MD) and Invitrogen (Carlsbad, CA). Gefitinib was obtained from Selleckchem (Houston, TX).

Generation and establishment of gefitinibresistant HCC827 cell line (HCC827/GR)

Well-characterized human non-small cell lung cancer cell line, HCC 827 was used as the parental line $(\mathrm{HCC} 827 / \mathrm{P})$ from which to develop the gefitinib-resistant cell line. The HCC 827/P cell line was serially subcultured through incrementally increasing gefitinib concentrations, starting with $0.01 \mu \mathrm{M}$ for approximately six months. The HCC $827 / \mathrm{GR}$ cell line retained the capacity for proliferation when returned to medium containing gefitinib $(1 \mu \mathrm{M})[6]$.

\section{3-(4,5-dimethylthiazol-2-yl)-2,5- diphenyltetrazolium bromide (MTT) assay}

A total of 2500 either HCC $827 / \mathrm{P}$ or HCC 827/GR cells were plated in 96-well flat bottom plates and then exposed to test the sensitivity of gefitinib at various concentrations. At the indicated times, $10 \mu \mathrm{lof} 1 \mathrm{mg} / \mathrm{ml}$ MTT (Sigma, St. Louis, MO) in PBS was added to each well for $4 \mathrm{~h}$. After centrifugation and removal of the medium, $150 \mu \mathrm{l}$ of DMSO (Sigma, St. Louis, MO) was added to each well to dissolve the formazan crystals. The absorbance was measured at $560 \mathrm{~nm}$ using an ELx808 Absorbance Microplate Reader (BioTek Instruments, Inc., Winooski, VT). Absorbance of untreated cells was designated as $100 \%$ and cell survival was expressed as a percentage of this value. Triplicate wells were assayed for each condition and standard deviation (SD) was determined [7].

\section{Clonogenic assay}

HCC $827 / \mathrm{P}$ or HCC $827 / \mathrm{GR}$ cells $\left(2 \times 10^{5}\right.$ cells) were seeded in $60-\mathrm{cm}$ dishes. $24 \mathrm{~h}$ after plating, various concentrations of gefitinib, were added to each dish. After treatment for 24 $\mathrm{h}$, cells were trypsinized and re-seeded in $60-\mathrm{cm}$ dishes at a density of 500 cells per dish in triplicate. The cells were further incubated for 13 days and stained with $0.5 \%$ crystal violet in PBS containing 25\% methanol. Colonies were examined under a light microscope and counted after capturing images by scanner. Relative colony numbers were calculated as a percentage of the untreated cells [7].

\section{RNA isolation}

Total RNA (including small RNAs) was extracted from HCC827/P or HCC827/GR cell 
lines using the mirVana miRNA Isolation Kit (Ambion, Austin, TX) according to the manufacturer's instructions. The quantity and quality of RNA were measured by Nanodrop 2000 thermo scientific spectrophotometer (NanoDrop Technologies, Wilmington, DE).

\section{miRNA microarray assay}

A miRNA microarray assay was performed using a service provider (PANAGENE, Daejeon, Korea). Briefly miRNA expression profiling of $\mathrm{HCC} 827 / \mathrm{P}$ or HCC827/GR cell lines were detected using the miRCURY LNA Array according to the manufacturer's recommended protocol. The ratio of red signal to green signal was calculated after background subtraction and normalization using a global LOWESS (Locally Weighted Scatter plot Smoothing) regression algorithm. Spots were flagged and analyzed for signal quality. The fold increase of miRNAs in HCC $827 / G R$ cell lines was determined by calculating these results according to the value of miRNAs in HCC827/P cell lines.

\section{Statistical analysis}

The comparison of miRNA values between HCC827/P and HCC827/GR cell lines was performed using a $t$-test. Results were considered significant in all experiments at * means $P<0.05$, ** means $P<0.01$ and *** means $P<0.001$. Data were expressed as the mean $\pm \mathrm{SD}$ of the mean.

\section{RESULTS AND DISCUSSION}

\section{Establishment of gefitinib-resistant $\mathrm{HCC827}$ cells (HCC827/GR cells)}

In order to investigate unknown mechanism of gefitinib resistance of NSCLC, first we generated the stable $\mathrm{HCC} 827$ cell line chronically resistant to gefitinib, $\mathrm{HCC} 827$ cells were used as the parental cell line (HCC827/P). The HCC $827 / \mathrm{P}$ cells were serially subcultured through incrementally increasing gefitinib concentrations, starting with $0.05 \mu \mathrm{M}$ for six months. Gefitinib-resistant $\mathrm{HCC} 827$ cells (HCC827/GR cells) retained the capacity for proliferation when returned to medium containing gefitinib $(1 \mu \mathrm{M})$. To confirm that the
HCC827/GR cell line accquired resistance against gefitinib, HCC827/P and HCC827/GR cells were treated with gefitinib in a dosedependent manner $(0,0.01,0.03,0.1,0.3,1,3$ and/or $10 \mu \mathrm{M}$ ) for $72 \mathrm{~h}$ and cell viability was evaluated by the MTT assay and the half maximal inhibitory concentration $\left(I C_{50}\right)$ was calculated by using CompuSyn software (ComboSyn, Inc., Paramus, NJ) [4]. The results showed that HCC827/GR cells were relatively resistant to gefitinib with an $I C_{50}$ value of 6.5 $\mu \mathrm{M}$, whereas $\mathrm{HCC} 827 / \mathrm{P}$ cells were relatively sensitive to gefitinib with an $I C_{50}$ value of 0.016 $\mu \mathrm{M}$ (fig. 1). The HCC827/GR cells demonstrated a 406.5-fold higher resistant index towards gefitinib than that of $\mathrm{HCC} 827 / \mathrm{P}$ cells. Next, we performed clonogenic assay to determine the long-term growth inhibitory effect of gefitinib in HCC827/GR and HCC827/P cell lines. Cells were treated with various concentrations of gefitinib $(0,0.01,0.1$, 1 , and/or $10 \mu \mathrm{M}$ ) for 1 day and continuously cultured in fresh media for 14 days and colony formation was measured by clonogenic assay. The result of clonogenic assay showed that HCC827/P cells showed increased sensitivity to gefitinib and HCC827/GR cells showed relatively resistance to gefitinib (fig. 2).

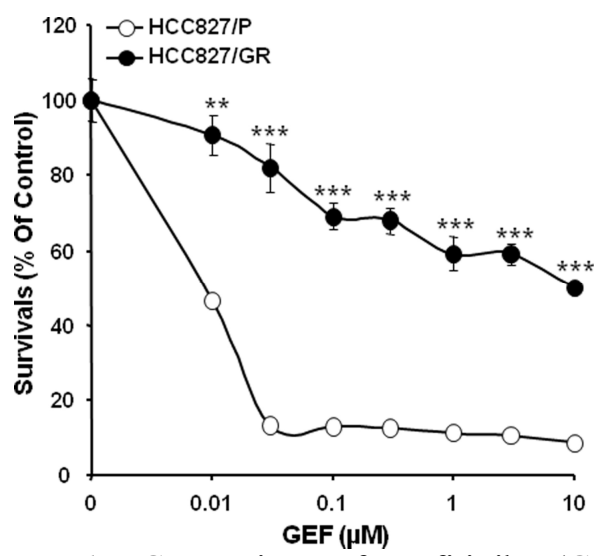

Figure 1. Generation of gefitinib (GEF)resistant HCC827 cells (HCC827/GR). The results of MTT assay of $\mathrm{HCC} 827 / \mathrm{P}$ and HCC827/GR cells, which were treated with GEF in a dose-dependent manner $(0,0.01,0.03$, $0.1,0.3,1,3$ and/or $10 \mu \mathrm{M}$ ) for $72 \mathrm{~h}$. Error bars represent the standard deviation. $* * P<0.01$ and $* * * P<0.001$. 


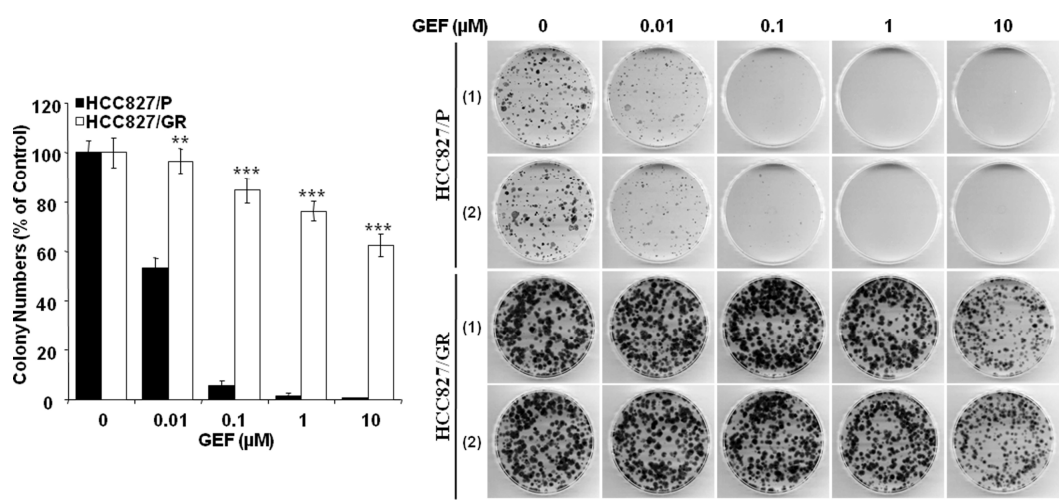

Figure 2. The clonogenic formation of gefitinib (GEF)-resistant HCC827 cells (HCC827/GR) and parental HCC827 cells (HCC827/P). A clonogenic assay of HCC827/GR and HCC827/P cells treated with GEM $(0,0.01,0.1,1$ and/or $10 \mu \mathrm{M})$ for $24 \mathrm{~h}$ was used to determine the long-term response. Colony numbers were counted and calculated as a relative percentage (\%) of the untreated control cells (left) and representative photograph of clonogenic assay results are shown (right). Experiments were repeated three times and similar results were obtained. Error bars represent the standard deviation. ${ }^{* *} P<0.01$ and ${ }^{* * *} P<0.001$.

Identification of miRNAs differentially expressed in gefitinib-resistant $\mathrm{HCC} 827$ cells (HCC827/GR) and parental HCC827 cells (HCC827/P)

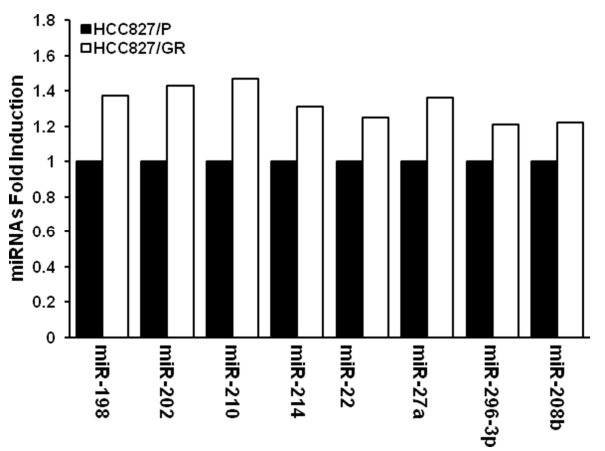

Figure 3. The miRNA profile fold induction as determined by Micorarray analysis of HCC827/GR cells relative to HCC827/P cells. Absolute value fold induction $>1.2$.

To identify miRNAs differentially expressed in HCC827/GR and HCC827/P cell lines, we analyzed miRNA expression profiles of HCC $827 / \mathrm{GR}$ and HCC827/P cell lines by miRNA microarray assay. The differential expression of miRNAs between these cells was determined by using the global locally weighted scatterplot smoothing (LOWESS) regression algorithm. The microarray data identified sixtyfive miRNAs differential expression between
HCC827/GR and HCC827/P cell lines (Data not shown). Moreover, comparing to $\mathrm{HCC} 827 / \mathrm{P}$ cells, eight significantly upregulated miRNAs (miRNA-198, miR-202, miR-210, miRNA-214, miR-22, miR-27a, miR-296-3p and miR-208b) with value fold induction higher than 1.2 in HCC827/GR cells (fig. 3) and fourteen greatly downregulated miRNAs (miR-135b, miR-141, miR-145, miR-153, miR-181c, miR-181d, miR188-3p, miR-197, miR-200c, miR-206-3, miR215, miR-216a, miR-296-5p and miR-30a) with value fold reduction lower than 0.7 in HCC827/GR cells (fig. 4). Taken together, these results suggest that the differential expression of miRNA profile between HCC827/GR and HCC827/P cell lines.

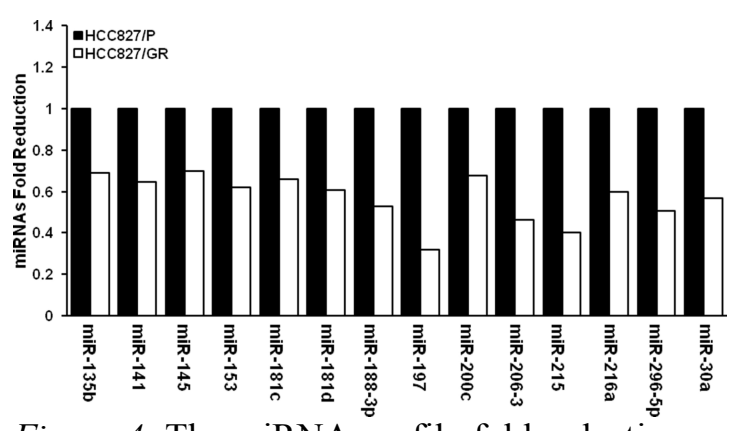

Figure 4. The miRNA profile fold reduction as determined by Micorarray analysis of HCC827/GR cells relative to $\mathrm{HCC} 827 / \mathrm{P}$ cells. Absolute value fold reduction $<0.7$. 


\section{DISCUSSION}

In this study, we investigated the miRNAs expression profile in gefitinib-resistant NonSmall Cell Lung cancer. We found that; i) The generation of HCC827/GR cells from HCC $827 / \mathrm{P}$ cells; ii) The identification of the differential expression of sixty-five miRNAs with eight significantly upregulated miRNAs and fourteen greatly downregulated miRNAs between HCC827/GR and HCC827/P. This is the report showing that the differential expression of miRNAs profile between HCC827/GR and HCC827/P cell lines.

Although chemotherapy is a standard treatment for NSCLC with response rates of $30 \%$ to $40 \%$, NSCLC patients eventually develop resistance to chemotherapy agents resulting in a median survival of only 8 to 10 months [2]. Recently substantial development in molecular targeted therapy is necessary approach in addition to chemotherapy to treat NSCLC because molecular targeted therapy drugs can interfere with and block specific molecular pathways that regulate critical cancer cell growth, survival and progression, such as EGFR signaling pathway. Although EGFRTKIs as gefitinib and erlotinib have been approved and used as the best strategy to treat NSCLC patients, almost all NSCLC patients develop resistance to EGFR-TKIs. It is well known that the occurrence of the mutation of EGFR at T790M and amplification of protooncogen MET account for $70 \%$ of acquired resistance to EGFR-TKIs in NSCLC $[13,17,8]$. Therefore the identification of new molecular mechanism of EGFR-TKIs and more effective treatments in NSCLC is extremely ultimate goal of cure and long-term control of NSCLC. Currently Chang et al. (2011) [3] showed that Slug, the regulator of epithelial-mesenchymal transition (EMT) contributes to the resistance of EGFR-TKIs as gefitnib in NSCLC and Xie et al. (2013) [21] showed Notch-1 contributes to EGFR-TKIs acquired resistance in NSCLC, suggesting that Slug and Notch-1 might play a novel role in acquired resistance to gefitinib which could be reversed by inhibiting Slug and Notch-1 in NSCLC.
An increasing body of recent publication investigates that miRNAs play a significant role in the molecular response to chemotherapy and radiotherapy in various kind of cancer types. Varying levels of sensitivity to chemotherapy and radiotherapy may be interred by the influence of up-regulation and down-regulation on miRNA on multiple mRNA targets and subsequent protein expression suggesting that the cellular response to chemotherapy and radiotherapy by the dysregulation of survival pathways, cell death, resistance, DNA repair system and/or metabolism [12,5,18,14,15,20]. The profile of miRNAs expression significantly associated with resistance of chemotherapy and radiotherapy was investigated in various kinds of cancer as ovarian cancer, bladder carcinoma and NSCLC $[18,14,15,20]$. For example; Sorrentino et al. (2008) [18] reported that five miRNAs (miRNA-let-7e, miR-30c, miR-125b, miR-130a and miR-335) were always diversely expressed in all the resistant ovarian cancer A2780 cell lines (A2780TAX, A2780TC1 and T2780CT3 (paclitaxel-resistant A2780) and A2780CIS (cisplatin-resistant A2780); miRNAlet-7e was up-regulated in A2780TAX cell line, while it was down-regulated in A2780TC1, A2780TC3 and A2780CIS cell lines; miR-125b was down-regulated in A2780TAX cell line but up-regulated in A2780TC1, A2780TC3 and A2780CIS cell lines; miR-30c, miR-130a and miR-335 were down-regulated in all resistant ovarian cancer A2780 cell lines suggesting that a direct involvement of miRNAs in the development of chemoresistance. Wang et al (2011) [20] also reported that 12 differently expressed miRNAs in the radiotherapy sensitivity and resistant NSCLC samples with five significantly up-regulated miRNAs (miR126, miRNA-let-7a, miRNA-495, miRNA-451 and miRNA-128) and seven greatly downregulated miRNAs (miRNA-130a, miRNA106b, miRNA-19b, miRNA-22, miRNA-15b, miRNA-17-5p and miRNA-21) explaining that these miRNAs may be used as candidate markers for radiotherapy sensitivity in NSCLC. In our study, we found that the differential expression of sixty-five miRNAs between HCC $827 / G R$ cells and HCC827/P cells; 
Moreover, we identified eight significantly upregulated miRNAs (miRNA-198, miR-202, miR-210, miRNA-214, miR-22, miR-27a, miR296-3p and miR-208b) and fourteen greatly downregulated miRNAs (miR-135b, miR-141, miR-145, miR-153, miR-181c, miR-181d, miR188-3p, miR-197, miR-200c, miR-206-3, miR215, miR-216a, miR-296-5p and miR-30a) indicating that these miRNAs may contribute to predict new mechanism of gefitinib resistance in HCC827 cell lines. However, we need to perform further experiments to determine their exact potential role and underlying mechanism.

\section{CONCLUSION}

We identified the miRNA expression profile with eight significantly upregulated miRNAs and fourteen greatly downregulated miRNAs that associated with the resistance of gefitinib in HCC827 cells suggesting the specific involvement of these miRNAs in the new mechanism of gefitinib resistance in NSCLC. Further studies are very necessary to investigate and explore the potential function of these miRNAs in NSCLC.

\section{REFERENCES}

1. Bartel D. P., 2004. MicroRNAs: genomics, biogenesis, mechanism and function. Cell, 116: 281-297.

2. Blackhall F. H., Bhosle J., Thatcher N., 2005. chemotherapy for advanced non-small cell lung cancer patients with performance status 2. Curr Opin Oncol., 17: 135-139.

3. Chang T. S., Tsai M. F., Su K. Y., Wu S. G., Huang C. P., Yu S. L., Lan C. C., Yang C. H., Lin S. B., Wu C. P., Shih J. Y., Yang P. C., 2011. Slug confers resistance to the epidermal growth factor tyrosine kinase inhibitor. Am. J. Respir. Crit. Care. Med., 183: 1071-1079.

4. Chou T. C., Talalay P., 1984. Quantitative analysis of dose-effect relationships: the combined effects of multiple drugs or enzyme inhibitors. Adv. Enzyme Regul., 22: 27-55.

5. Croce C. M., Calin G. A., 2005. miRNAs, cancer, and stem cell division. Cell, 122: 6-7.
6. Duong H. Q., Hwang J. S., Kim H. J., Kang H. J., Seong Y. S., Bae I., 2012. Aldehyde dehydrogenase $1 \mathrm{~A} 1$ confers intrinsic and acquired resistance to gemcitabine in human pancreatic adenocarcinoma MIA $\mathrm{PaCa}-2$ cells. Int. J. Oncol., 41: 855-861.

7. Duong H. Q., Kim H. J., Kang H. J., Seong Y. S., Bae I., 2012. ZSTK474, a PI3K inhibitor, suppresses proliferation and sensitizes human pancreatic adenocarcinoma cells to gemcitabine. Oncol Rep., 27: 182-188.

8. Engelman J. A., Zejnullahu K., Mitsudomi T., Song Y., Hyland C., Park J. O., Lindeman N., Gale C. M., Zhao X., Christensen J., Kosaka T., Holmes A. J., Rogers A. M., Cappuzzo F., Mok T., Lee C., Johnson B. E., Cantley L. C., Janne P. A., 2007. MET amplification leads to gefitinib resistance in lung cancer by activating ERBB3 signaling. Science, 316: 1039-1043.

9. Filipowicz W., Bhattacharyya S. N., Snonenberg N., 2008. Mechanisms of posttranscriptional regulation by microRNAs: are the answers right? Nat Rev Gene., 9: 102-114.

10. Hamilton W., Peters T. J., Round A., Sharp D., 2005. What are the clinical features of lung cancer before the diagnosis is made? A population based case-control study. Thorax, 60: 1059-1065.

11. Jemal A, Thun MJ, Ries LA, Howe HL, Weir HK, Center MM, Ward E, Xu XC, Eheman C, Anderson R, Ajani UQ, Kohler B, Edwards BK (2008) Annual report to the nation on the status of cancer, 1975-2005, featuring trends in lung cancer, tobacco use and tobacco control. J. Natl. Cancer Inst., 100: 1672-1694.

12. Kloosterman W. P., Plasterk R. H., 2006. The diverse functions of microRNAs in animal development and disease. Dev Cell, 11: 441-450.

13. Kobayashi S., Boggon T. J., Dayaram T., Janne P. A., Kocher O., Meyerson M., Johnson B. E., Eck M. J., Tenen D. G., 
Halmos B., 2005. EGFR mutation and resistance of non-small-cell lung cancer to gefitinib. N Engl J Med, 352: 876-892.

14. Kozinn S. I., Harty N. J., Delong J. M., Deliyiannis C., Logvinenko T., Summerhyes I. C., Libertino J. A., Holway A. H., Rieger-Christ K. M., 2013. microRNA profile to predict gemcitabine resistance in bladder carcinoma cell lines. Genes Cancer, 4: 61-69.

15. Li X., Lu Y., Chen Y., Lu W., Xie X., 2013. microRNA profile of paclitaxel-resistant serous ovarian carcinoma based on formalin-fixed paraffin embedded samples. BMC Cancer, 13: 216.

16. Mitsudomi T., Kosada T., Endoh H., Horio Y., Hida T., Mori S., Hatooka S., Shinoda M., Takahashi T., Yatabe Y., 2005. Mutations of the epidermal growth factor receptor gene predict prolonged survival after gefitnib treatment in patients with nonsmall-cell lung cancer with postoperative recurrence. J Clin Oncol, 23: 2513-2520.

17. Pao W., Miller V. A., Politi K. A., Riely G. J., Somwar R., Zakowski M. F., Kris M. G., Varmus H., 2005. Acquired resistance of lung adenocarcinoma to gefitinib or erlotinib is associated with a second mutation in the EGFR kinase domain. PloS Med., 2: e73.
18. Sorrentino A., Liu C. G., Addario A., Peschle C., Scambia G., Ferlini C., 2008. Role of microRNAs in drug-resistant ovarian cancer cells. Gynecol Oncol., 111: 478-486.

19. Takano T., Ohe Y., Sakamoto H., Tsuta K., Matsuno Y., Tateishi U., Yamamoto S., Nokihara H., Yamamoto N., Sekine I., Kunitoh H., Shibata T., Sakiyama T., Yoshida T., Tamura T., 2005. Epidermal growth factor receptor gene mutations and increased copy numbers predict gefitinib sensitivity in patients with recurrent nonsmall-cell lung cancer. J Clin Oncol., 23: 6829-6837.

20. Wang X. C., Du L. Q., Tian L. L., Wu H. L., Jiang X. Y., Zhang H., Li D. G., Wang Y. Y., Wu H. Y., She Y., Liu Q. F., Fan F. Y., Meng A. M., 2011. Expression and function of miRNA in postoperative radiotherapy sensitive and resistant patients of non-small cell lung cancer. Lung Cancer, 72: 92-99.

21. Xie M., He C. S., Wei S. H., Zhang L., 2013. Notch-1 contributes to epidermal growth factor receptor tyrosine kinase inhibitor acquired resistance in non-small cell lung cancer in vitro and in vivo. Eur $\mathrm{J}$ Cancer, 49: 3559-3572.

\title{
NGHIÊN CỨU ĐÁNH GIÁ SỰ BIỂU HIỆN CỦA miRNAs \\ TRONG DÒNG TẾ BÀO UNG THU' PHỔI KHÔNG TẾ BÀO HẠT NHỎ HCC827 KHÁNG THUỐC ĐIỀU TRI TRÚNG ĐÍCH GEFITINIB
}

\author{
Dương Hồng Quân ${ }^{1,2}$, Seong Yeon-Sun ${ }^{2}$ \\ ${ }^{1}$ Trường Đại học Duy Tân, Đà Nẵng, Việt Nam \\ ${ }^{2}$ Trường Đại học Dankook, Cheonan, Hàn Quốc
}

\section{TÓM TẮT}

Gefitinib và erlotinib, chất ức chế hoạt tính tyrosine kinase (tyrosine kinase inhibitors) của thụ thể yếu tố tăng trưởng biểu bì (EGFR, epidermal growth factor receptor), được biết đến như là thuốc điều trị ung thư trúng đích đầy triển vọng trong điều trị bệnh nhân ung thư phồi không tế bào nhỏ. Ban đầu, bệnh nhân ung thư phổi không tế bào nhỏ có đột biến ở exon 18-21 của gen EGFR có đáp ứng tốt với thuốc điều trị trúng 
đích gefitinib và erlotinib. Tuy nhiên, sau một thời gian bệnh nhân ung thư phổi không tế bào nhỏ được điều trị bằng liệu pháp trúng đích đã dẫn tới việc kháng lại thuốc điều trị trúng đích. Các nghiên cứu gần đây đã thông báo có hai cơ chế kháng thuốc điều trị trúng đích chủ yếu như hình thành đột biến thứ cấp T790M của gen EGFR và sự khuếch đại biểu hiện của protein c-MET. Các cơ chế kháng thuốc điều trị trúng đích khác vẫn đang trong quá trình nghiên cứu và phát hiện. Thời gian gần đây, microRNAs (miRNAs) được biết đến như là phân nhóm RNA điều hòa sự biểu hiện gen thông qua sự gắn kết miRNA-mRNA. miRNAs điều hòa quá trình sau phiên mã quan trọng giúp điều hòa quá trình biểu hiện gen đối với quá trình phát triển tế bào, sự tăng sinh tế bào, sự kháng lại liệu pháp họa trị và xạ trị cũng như quyết định quá trình tế bào chết có chương trình. Vì vậy, mục đích của nghiên cứu này là đánh giá và xác định sự biểu hiện của các miRNAs liên quan tới sự hình thành khả năng kháng thuốc điểu trị ung thư trúng đích gefitinib trong ung thư phổi không tế bào nhỏ. Trong nghiên cứu này, chúng tôi đã đánh giá mức độ biểu hiện của các miRNAs trong dòng tế bào ung thư phổi không tế bào nhỏ HCC827 kháng thuốc gefitinib (HCC827/GR) so với dòng tế bào ung thư phổi không tế bào nhỏ HCC827 ban đầu $(\mathrm{HCC} 827 / \mathrm{P})$ bằng phương pháp miRNA microarray. Kết quả phân tích của phương pháp miRNA microarray so sánh mức độ biểu hiện của các miRNA giữa dòng tế bào HCC827/GR và HCC827/P đã xác định được sự biểu hiện khác nhau của 65 miRNAs trong đó so với dòng tế bào HCC827/P ban đầu, dòng tế bào HCC827/GR có sự gia tăng mạnh nhất sự biểu hiện của 8 miRNAs (miRNA-198, miR-202, miR-210, miRNA-214, miR-22, miR-27a, miR-296-3p and miR-208b) và giảm mạnh nhất sự biểu hiện của 14 miRNAs (miR-135b, miR-141, miR-145, miR-153, miR-181c, miR-181d, miR-1883p, miR-197, miR-200c, miR-206-3, miR-215, miR-216a, miR-296-5p and miR-30a). Kết quả nghiên cứu đánh giá sự biểu hiện của các miRNAs trong dòng tế bào HCC827/GR góp phần hiểu biết hơn về cơ chế phân tử mới liên quan đến tính kháng hoặc đáp ứng tốt với thuốc điều trị gefitinib để từ đó cung cấp thông tin hữu ích trong việc phát triển phác đồ điều trị mới trong điều trị bệnh nhân ung thư phổi không tế bào hạt nhỏ với thuốc điều trị trúng đích gefitinib.

Tù khóa: Sự biểu hiện miRNA, liệu pháp điều trị trúng đích, sự kháng thuốc gefitinib, ung thư phổi không tế bào nhỏ, dòng tế bào HCC 827 .

Ngày nhận bài: 12-1-2015 